\title{
Perpetrator Plays the Victim: The Politics of Representation in the Captivity Narratives of the Whites
}

\author{
Virender Pal \\ Assistant Professor, Institute of Integrated EHonors Studies, Kurukshetra University \\ Kurukshetra, Haryana, Email: p2vicky@gmail.com, v_pal@kuk.ac.in, ORCID ID oooo- \\ ooo3-3569-1289
}

\begin{abstract}
This paper draws upon and brings into focus an interesting part of the colonial corpus- the captivity narratives. The discoverers of the New World who then shortly turned invaders had to face resistance from the Natives as they embarked upon their conquest, usurpation and assumption of Property in the virgin lands of the continent lying unexploited till the White man set foot on it. To rightfully and legally take that did not belong to the White intruders they had to be morally, culturally and even ethically superior. This question of 'Might is Right' is resolved easy through legal systems and machinery on one hand and narratives and discourse and institutions on the other. The Captive Narratives were put to work operating to dub and dismiss the Native. The captive narratives though taken together as a body worked as a device to denigrate the Natives and typecast them so that their extermination would be found as relieving rather than horrendous; as a step towards safety rather than a brutal incursion, they also offered rare insights when not written as part of a strategy but as biographical accounts of Whites held captive by the Reds. Especially, accounts that do not fall neatly onto the timeline set by the White diverge from popular, touted, dominant accounts that underscore barbaric customs of the Reds. These rare narratives by White people brought up by Natives cast a different light on the Red culture and offer substantial clues that the Red way of life was preferable.
\end{abstract}

Keywords: New World, Red Indians, Natives, Captivity Narratives, Land, Federal Laws, representations, colonization

\section{Introduction}

Captivity narratives became immensely popular in America after the publication of Narrative of the Captivity of Mrs. Rowlandson in 1682. Though it was not the first captivity narrative, it was the most influential one. These captivity narratives marked a change in the image of the Native who were earlier described as "ecologically noble savage" (Ross \& Pickering 2002, p.191) so far by the colonial narratives. The captivity narratives followed a set story pattern (though they were based on supposedly real abductions, most of them were written by Cotton Mathers on behalf of the abducted people) where a white woman was captured by the Natives and the story concentrated on her trials and tribulations and her ultimate restoration to the white society. For the Puritans "these captivities came to epitomize the spiritual trial posed to the colonists by the American wilderness, its savage inhabitants, and perhaps most importantly the savagery within themselves" (Strong 1999, p.1).

(C) AesthetixMS 2020. This Open Access article is published under a Creative Commons Attribution Non-Commercial 4.o International License (http://creativecommons.org/licenses/by-nc/4.o/), which permits non-commercial re-use, distribution, and reproduction in any medium, provided the original work is properly cited. For citation use the DOI. For commercial re-use, please contact editor@rupkatha.com. 


\section{Label and Dismiss: Savages or Safety?}

These captivity narratives may be read in connection to the American-Indian wars. When the 'noble savages' realised the greed of whites for the land, they started fighting for the land. Now with the onset of these wars the image of 'noble savage' had to be destroyed.Noble savage is indeed an oxymoron but it seems to have been used to denote the capability of the 'savage' to be noble. There is no indication that the Whites placed any value on the language or culture developed by the natives. In fact, the white man's superiority lies in upholding his own language and culture and completely relegating that of others.

Noble savage at the same time is a grudging acknowledgment and the little admission, confession, and a token of praise grudgingly bestowed on the Natives who were not at all 'savage' but had a distinct way of life, inexplicable, incomprehensible and inimitable because the White mind could only live by self-gratification, ownership and possessions.

The captivity narratives did the job commendably well in destroying one fictional image and then replacing it with another. Now the Natives were depicted as savages who were ahead of the animals on evolutionary ladder because they had developed a language (Strong 1986, p.181) otherwise they retained the barbarity and cruelty of the animals. Most of the narratives produced during the American wars paved the way for stereotyping the Natives as "savage, dark, idolatrous and uncivilized" (Trafzer 1999, p.6). The depiction of Natives as savages took away the sympathy that existed for them and paved the way for their extermination.

\section{Odd Preferences}

The captivity narratives portrayed the torture that the whites had to undergo in the captivity of the Natives, but they hide a vital truth. These biased narratives do not tell that most of the captives preferred to live in Native society rather than white society. Wilcomb E. Washburn writes:

Most of us know that an extraordinary number of whites preferred Indian society, while almost no Indians preferred white society. (1957, p.52)

The narratives which narrate such situations are a few; but they have captured the imagination of the readers. One such narrative is The Light in the Forest by Conrad Richter. The paper is a study of the same novel.

\section{It's Different}

The novel The Light in the Forest is a remarkable achievement of the author and a bold one too because it was written during the times when the public opinion against the Natives was whole time low. Publishing such book was a risky venture at that time as it would have failed to gain readers among the whites, but Richter did remarkably well revealing why the whites preferred Native society in comparison to their own.

\section{Rational Whites are also Supreme Myth-makers}

The writer tells the story of True Son/ John, a white boy who has been adopted by the Natives. In the process of telling the story Richter demolishes many myths about the Natives. The white army comes to take the white captives from the Natives; but most of the white captives do not want to go. Though the writer centres on the story of True Son who resists going back to the white society, he drops subtle hints that all the whites wanted to remain in the Native society. 


\section{Cultural Shock: Capitalist encounters with the Egalitarian}

Richter shows that Native society is an egalitarian society where everyone is equal. This is a society where "meanness" (Richter 1953, p.8) of the whites does not exist. The Natives enjoy a life style that was enjoyed by the whites only during vacations. They "fished, hunted and played" (Richter 1953, p.7-8) throughout their lives. In fact, this was the greatest offence of the Natives. In Europe fishing and hunting was a privilege only. The people belonging to aristocratic and rich family could enjoy. James Axtell comments:

William Byrd II, the English-bred scion of one of the wealthiest families in Virginia indicated that the Indians greatest offense was the usurpation of aristocratic privilege, the disorderly jumping of class lines. For in England the only people who hunted were members of the upper classes, who did not kill to eat, or poachers who did and risked their ears-or necks-in the attempt. Forests were not public property but belonged to the nobility property who regarded them as private game reserves. (1981)

True son had enjoyed all the fruits of Native life. He does not want to leave his home, the forest because for him white life meant incarceration. For the Natives, living in enclosed house meant living in a prison. True son is acutely aware of this difference: "Why did the white race imprison itself in houses and barns when life giving forest stood all around?" (Richter 1953, p.78).

\section{Locked by Greed}

When True son starts living in the house of his white parents, he realises that "Now he was thrice imprisoned-first in this alien land, then in this Yengwe house and room, and last in this white boy's clothing" (Richter 1953, p.60). These lines show that living with the whites has changed his perspective towards the whites. Their "houses look ugly" (1953, p.10) and tents "pale" (1953, p.10) to him.

The novelist also makes clear the difference between the Native society and the white society. For the whites True Son is a prisoner (Richter 1953, p.8), but to Natives he is the son. This is not the case with True son, only; rather all the so- called 'white prisoners' were taken as family members. The bond between the white prisoners and their Native families is so strong that they do not want to leave their Native families. Even the white army men were surprised to find that the Natives cried like women as they gave up some white child or wife" (1953, p.16-17). The white also realized that the white prisoners were not interested in going back to the white society:

But what many of the men couldn't get over the was the ungratefulness of the captives. They didn't want to have anything to do with the whites who had risked their lives to rescue them. They called out in Delaware to their Indian masters to take them back again to their Indian homes. (Richter 1953, p.16)

The theme of freedom versus incarceration is reinforced throughout the novel. The Natives represent freedom; while the whites represent incarceration.

The whites are not incarcerated in their homes and barns and cities, but they are also incarcerated by their greed and wants. Only they do not realize their imprisonment. The imprisonment of whites is made clear by the Negro basket maker who tells:

No. I'm never free from white folks. And neither are you and your brother Everyday they drop another fine strap around you. Little by little they buckle you so don't feel it too much at one time. Sooner or later they have you all hitched up, but you've got so used to it by the time you hardly know it. (Richter 1956, p.73) 
True son is not used to this imprisonment.

\section{Homesick and Displaced: Out of Culture, Out of Place}

He has tasted the freedom while living with his Indian family so he is able to compare both the societies and the lifestyle offered by both in the white society means to live in a prison. "Homesickness" overwhelms him (Richter 1956, p.11) while living with the whites.

\section{Account Keepers: Blood Quantum to Culture}

The White man loves to quantify everything- even measure subjectivities and abstract feelings. They are the ace data cullers and account-keepers. Their greatest instrument is law and legality which at its basic level is all partial and thoroughly favours the Whites. However, the Natives do not see the truth that way. It is the culture, upbringing and values that determine for them the identity rather than genes, blood or inheritance- the lived part. The Indian stand on nature versus nurture debate clearly favours nurture but this 'nurture' itself is organic to nature and in rhythm with it, therefore striking at the very roots of the debate and exposing the fact that life and living cannot be against nature but with and within nature- there is not the debate but harmony that the Indians highlight.

Richter also contributes to the identity debate that is going in the American society through this novel. In the contemporary American society, the identity of Indians is strictly regulated by the federal government and the tribes.

The most important criteria that has been adopted by the federal government and the Natives is that of blood quantum.

Most of the Native writers have asserted that the criterion of blood quantum is not appropriate. They assert that culture and a distinct worldview are the aspects that differentiates Natives from the whites and the other groups (Devi et al 2019,p.5). Many Native American writers have pointed out this difference. Tinker, for instance points "out the communitarian-individualist difference between Indian and Euro-Western cultures” (2003, p.XII).

The colonial government took so many Native children to educate them in colonial Indian school where they were shorn of their Native culture. Some of these children were full-blooded children, but they were not Indians in essence because they never developed the distinctive worldview. This person will be considered as an Indian because of his blood, but a non-Indian who has been initiated into culture by the Indians and who is Indian is every sense of the world becomes a non-Indian.

The debate about the identity of the Indians was further complicated when Shania Twain who is a member of Ojibwe tribe was engulfed in a controversy. Shania Twain was adopted by an Indian as a child. Some people said that she was a white because her biological parents were white. Shania Twain's reply to her critics accentuated her identity as an Indian. She may not be an Indian by blood, but culturally every cell of her body is Indian. She explained:

I don't know how much Indian blood I Actually have in me, but as the adopted daughter of my father Jerry, I became legally registered as 50-percent North American Indian. Being raised by a full-blooded Indian and being part of his family and their culture from such a young age is all I've ever known. That heritage is in my heart and my soul and I'm proud of it. (Cited in Garroutte 2003, p.39)

Richter also seems to endorse Shania Twain's statement that Indian is a cultural identity. Essence of being an Indian does not depend on blood or skin colour. It depends on nurture and 
culture when the white soldiers try to remind True Son of his white ancestry, he replies: "Nobody can help how he is born" (Richter 1956, p.17). It is clear that True Son is an Indian by choice. He has been nurtured in Indian culture by the Natives and he has developed that distinctive worldview where earth is considered as "Mother" (1953, p.85).

\section{Cultural Ethos: Community or Competition}

Now the world has come to know about the philosophy of Indians through literature. However, it must be understood that the Richter's book was first published in 1953 sixteen years before "renaissance" of Native literature which was an attempt to "recover traditions, beliefs and even languages that were lost, suppressed or marginalized during a centuries-long history of conquest" (Henderson 2011, p.477). Richter projected about the Native worldview in this book and contributed to the cause. Native Americans culture sees "profound interconnectedness of all existence' as a "sacred hoop" (Eagle Man, 1990, p.15).

\section{Part of it: Not the Owner of the Whole}

This concept of Sacred Hoop shows that man is not superior to all other creations, rather he is a part of the circle and all the other creatures are equal and important part of this circle. This worldview is in direct contrast with the white world view. The Native literature has contrasted this worldview in their literature. Linda Hogan, for instance, in her novel Mean Spirit brings out the difference. In the novel, a Native character Horse asks the Christian Priest:

For Instance, where does [The Bible] say that all living things are equal?" The priest shook his head. "It doesn't say that it says man has dominion over the creatures of the earth." "Well, that's where it needs to be fixed. That's the part of the trouble, don't you see?" (35)

Richter shows that True Son has imbibed the culture of the Natives. He also considers that all the living and non-living beings are connected to one another. Richter tells the readers about his thoughts:

His father, the Sun had already risen. Around him his sisters, the birds, sang. His brother the black squirrel coughed at him. His mother, the Earth bore him up on her breast, while all his small cousins that stood or ran upon earth spoke their scents to him (1953, p.116).

These lines make clear that Richter also believes that Indian is a cultural entity. True Son, though born to white parents is culturally an Indian.

Richter in fact, anticipates the issues that were to be taken up by the Native writers. One of the most important issues taken by the Native writers is that of materialistic nature of the whites. Richter also mocks at this behaviour of the whites:

They are young and heedless like children. You can see it the way they head up treasures

like a child, although they know they must die and can't take such things with them. (1953, p.31)

This life style was alien to the Native who followed the tribal way of life where community was important and everything belonged to everybody. In this society "orphans and the aged were invariably cared for, not only by their next of kin, but by the whole clan" (Eastman 2003, p.27). The tribe acted as an extended family and this explains why the Natives were able to adopt True Son as one of their own. The longing of True Son for his Indian family shows that he was loved and cared for by them. The white way of life has been criticised by Native writers all over the world. 
Noted Australian Aboriginal writer Kevin Gilbert, for instance, declares that the Native way was a:

Superior way of life, devoid of competitive sharking ruthlessness in the white society. We believe that the old laws were just wise and good and provided an umbrella for the growth of the human spirit. Certainly most of us believe that it was not until the white man came that greed, lust, arrogance and meanness came to the Eden that was Australia. (Gilbert 1973, p.146)

\section{Lawless Indians: But who requires the laws?}

The virtues of tribal life were espoused by the white writers also. Charles Erskine Scott Wood, for instance, wrote about the Natives:

I have known people without "State" or "Statesmen;"

And without gallows, jails, places, police or slums;

No poverty nor crime-none dreamed a man,

Above the cunning, grey coyote-thief,

Could have a wish to steal the common heritage...

(Cited in Smith, Sherry L. 200o, p.40)

The society of the Natives was a greedless, moneyless and crimeless society where every member of the tribe was a part of the family. On the other hand, the white society is a materialistic and greedy society.

\section{The Subaltern Has a Smaller Carbon Footprint}

The consequences of this greedy life style are now visible in the environmental degradation. The whites have destroyed the environment. Environmental damage is the direct outcome of white man's greed:

And now he saw he had reached a point he had often heard about, the sad, incredible region where the Indian forest had been cut down by the White destroyers and no place left for Indians game to live. Here the desolate face of the earth has been exposed to dead brown weeds and stubble, boarded over by the lodges of the white people and the fat storehouses of their riches. (1953, p.39)

In this case also, Richter anticipates the Native writers. Of course, Richter did not know about the depth of relationship between the Natives and the surroundings, but he rightly anticipated the environmental problems that followed.

Later Leslie Marmon Silko wrote that the "dead objects: the plastic and neon, the concrete and steel" (1977, p.190) were destroying the planet.

The novel also anticipates the criticism of Christianity by the Natives. In fact, when the Europeans arrived in Americas they were perplexed to see the Native religion. Sam Gill, a scholar of Native American studies articulated the problem:

(In)n terms of my training as a student of religion, I had no text, no canon which to base an interpretation of... highly complex events. There is no written history, no dogma; no written philosophy, no holy book. (Cited in Balgangadhara 2013, p.11)

The Native religion did not have the components of European faith like a prophet, a holy book and a church so it was not considered a religion and was declared that Natives were Satan 
worshippers. Subsequently, a critique of Christianity was developed by the Natives. Richter gives voice to that criticism:

The whites were very childish to believe that the God of the whole Universe would stay in such a closed up and stubby place. The Indians knew better-that the Great Spirit loved the freedom of woods and streams where the air blew pure, where the birds sang sweet. (1953, p.70)

Richter also reveals the hypocrisy of the whites. Though the whites were Christians and tried to decimate Native traditions and culture in the name of Christianity; they were inherently hypocrites. True Son tells the whites:

Indian only swear like he learns from the White man. My father says when he is a boy he hears white man says God damn. God damn when it rain and God damn it powder don't go off. Then somebody tells him that God damn mean- that the Great Spirit must burn it in hell fire forever. He is surprise. How could the Great Spirit bother to burn in hell fire forever powder that don't go off? For why would he burn rain when he made rain and sent it on earth? (Richter 1953, p.88)

This shows that the whites only care for their benefit. They use the swear word even against God for their mistakes, but they did not hesitate committing "cultural genocide" by robbing their religious view of another people" (Horn 2003, p.66). The Native's concept of religion is different, it aims to maintain the balance of the earth and preserve the species, on the other hand, religion had been adopted by the "western peoples in their economic exploitation the earth" (Deloria 1973, p.81)

The whites only considered earth as a source of economic riches, while the Native had a spiritual connection with the land. It was a source of their religion, culture and essential for their physical and mental health. In fact, when the whites arrived in Americas, Natives, helped them in surviving in an inhospitable terrain. They were described as "so tractable, so peaceable" (Cited in Brown 1970, p.1) by Columbus. The Natives saved the whites from starvation in the initial days and taught how to grow maize. It is clear from Powhatan's complaint to English colonists:

What will it avail you to take that perforce [which] you may quietly have with love or to destroy them that provide you [with] food? What can you get by war, when we can hide our provision and fly into the woods, whereby you must famish, by wronging us, your friends? (Cited in page 2004, p.161)

\section{American history: Monologues of the Victorious}

In the beginning of conquest, the Natives believed that the continents of Americas had enough for both groups; but then they realised that the whites were greedy and wanted to take over the whole continent by uprooting the Natives from their traditional land. The conflict started when the Natives realised that the whites "were takin' over country" (1953, p.15).

American history is the history written by the whites. This history is a long monologue on the achievements of whites where Natives seldom get mentioned. In this history "every little action by Native Americans against the settlers during the Revolution has been carefully preserved-cherished, even-in western records, the daily atrocities committed against Native" (Mann, 2005, p.15) remain unnoticed. 


\section{Subaltern Histories}

Literary writers have started writing history of colonial America from the point of view of the Natives. Richter also plays his role in the project. He brings the massacre of Conestogo Indians to the notice. The massacre of the Conestogo was abominable because they had converted to "white man's religion" (1953, p.57). Some "white savages from Peshtank" came and killed the Conestogo (1953, p.57). The local whites of the town did not lift their hand to save the Natives. The incidence shows that the local whites had a tacit understanding for the massacre of the Natives.

The Natives were declared "barbarians" (Maddox 1991, p.63) by the whites. The image of Native as savage barbarians did not remain confined to the continent of America, rather it travelled across the Atlantic to Europe. The people in England "used North American Indian as a benchmark for barbarity and depravity.

\section{Questioning Stereotypes}

Horace Walpole often used references to American Indians to shame and insult those whom he loathed: impolite companions were 'Iroquois' and the rabble were 'Cherokee' (Cited in Bickham 2005, p.96) and an article in Jackson's Oxford Journal accused the Indians of roasting "their Prisoners alive" (Cited in Bickham 2005, p.97). In the novel, Richter shows that the real barbarians were the whites who did "indecencies" (1953, p.58) and "chopped off the hands of the men and squaws" (1953, p.58). True Son shows the mirror to the whites:

But you were Christian, you had forty, fifty men. You had horses, knives, tomahawks and rifles. You blow heads off of Indian men. You kill Indian women and young ones. Not one is left, you scalp. You chop. You cut off hands and try to cut off feat (1953, p.65).

Richter unravels the real face of the whites. American history written by the whites is lopsided. It describes the 'battles' fought by the whites and massacres' committed by the Natives. Richter makes clear that it was the whites who killed children and women. They were the real savages who were not satisfied with killing only, they cut off the limbs of the dead bodies to satisfy their atavistic urges. The incidents of violence narrated by Richter are not fictional. Thomas King also narrates incidences that confirm the barbarity of the whites:

In 1598, in what is now New Mexico, Juan de Onate and his troops killed over eight hundred Acoma and cut off the left food of every man over the age of twenty-five. In 1637, John Underhill led a force that killed six to seven hundred Pequot near the Mystic River in Connecticut. (King. 2012, p.5)

Thomas King mentions many such massacres to make clear that these massacres occurred at regular intervals.

The Natives were accused by the whites of killing and scalping white children. True Son makes clear that his people never "ever did anything bad and horrible like scalping white. White Children and dashing their poor brains out against a tree" (1953, p.88). In fact, True Son is himself a testimony of the fact that the Natives were not "cowards" (1953, p.89) who killed children. True Son was not killed by the Natives, rather he was lovingly brought up by them as their own.

The Natives were also accused of scalping the whites. There is a reference to scalping (p.24, 88, 133) in the novel. The novel drops hints that the whites practised scalping. James Axtell points out that "it has been widely held that the Indians did not practice scalping until they were taught the bloody technique by invading Europeans in the seventeenth century through the use of scalp bounties" (1988, p.252). In another book, Axtell quotes Susette La Flesche who asked: 

the Whites

Don't you know that the white man taught Indian that? It was practiced in New England on Penobscat Indians. The General Court of the Province of Massachusetts offered a bounty of forty pounds for every scalp of a male Indian brought in as evidence of his being killed, and for every scalp of female or male Indian under twelve years, twenty pounds. $(1981)$

Richter also seems to confirms that whites were indeed money for the scalps of the Indians. He tells the readers through True Sons.

Once a white man lived with Indians. He married Indian woman along Musking. They had three young ones. All girls. On day white man makes mind he gets back to his people. He kills his squaw and three girls. He takes their scalps back to Philadelphia for scalp money. (1953, p.67)

The incidence at once informs that the whites started scalping for the money; at the same time, it accentuates the inhumanity of the whites who could kill even their children for money. On the other hand, True Son does not allow Half Arrow to kill a white man who called "himself" his uncle (1953, p.113).

Richter reinforces inhumanity of the whites through other incidences also. When confronted by True Son, Parson Elder admits: "Sometimes even the most exemplary Christians get out of hand" (1953, p.89). The Parson's face "turns white" (1953, p.90) when True Son tells him that Indians never killed women and children. Parson does not refute True Son, but his reaction shows that the whites have been perpetrating lies about the Natives to brand them as beasts and savages.

Conrad Richter was a white who had only a second-hand knowledge about the Native society. The novel shows that he had done considerable research about the Native society and white colonial history, but there are some lacunae is his knowledge.

He cannot be blamed for these gaps because when he wrote the novel, at that time the Native literature was not available. Anybody who had read literature written by the Natives can understand that he did not know about the position of women in Native society.

For instance, True Son "felt debased" while "obeying a white squaw, made a carry with his hands a bucket of steaming water up the stairs. That was woman's work back along the Tuscarawas" (1953, p.6o). Richter was sure that the Native society was a patriarchal society where women were considered beasts of burden. Richter seems to convey that women were slaves in the Native society:

He [True Son's White Father] was still incomprehensible to his son, in dress and sex like a man and yet unable to rule his own squaw, but being ruled by her, obeying her slightest wish, plying other to do her work while she spent her life in her room like a sleek white rat in its cage. (1953, p.102-103)

The Native writers have refuted these allegations of the whites.

\section{Dissent within the Native defence}

Paula Allen Gunn says that "American Indian have based their social systems, however diverse, on ritual, spirit-centred, woman-focused world-views" (1986, p.2). She calls her people "gynocratic or gynocentric tribal people" (1986, p.3) and "last surviving Mother-Right peoples on the planet" (1986, p.11). 
Indian society was different; it was matrilineal society where women was the head of the family. In Ceremony, Silko writes that house "belonged to old grandma and Auntie" (1977, p.29). The women own the property: "The Sheep, the horses and the fields everything belonged to them, including the good family name" (1977, p.29). Louise Erdrich also shows that Nokomis is the head of the family in the novel The Birchbark House (1999, p.111)

\section{Remnants of Destroyed Utopias}

Thus, the novel The Light in the Forest makes clear a significant departure from the captivity narratives. In the novel, the Natives come across as benevolent and innocent people who were branded as uncivilized only because the whites wanted to usurp the land. The novel demolishes the myths and stereotypes perpetrated about the Natives. It is a Native novel written by a White before the advent of "Native renaissance". The Native at the same time tells the reasons why Native society and life was much better than the white society. The Natives were living in a utopia that was corrupted by the whites.

\section{Reference}

Allen, Paula Gunn. 1986. The Sacred Hoop. Boston: Beacon Press.

Axtell, James. 1981. The European and the Indian: Essays in Ethnohistory of Colonial North America. [Kindle paperwhite version] Retrieved from amazon.in.

Axtell, James. 1988. After Columbus: Essays in the Ethnohistory of Colonial North America. New York. Oxford University Press.

Bickham, Troy O.2005. Savages With in the Empire: Representations of American Indians in EighteenCentury Britain. Oxford: Clarendon Press.

Brown, Dee. 1970. Bury My Heart at Wounded Knee. New York: Picador.

Deloria Jr., Vine. 1973. God is Red. Colorado: Fulcrum Publishing.

Devi, Babita, Divyajyoti Singh \& Satinder Kumar Verma. 2019. Natives' Naivety vis-à-vis Settler

Skepticism and Bible's Belief: Restoring,'re-storying' the Native Ceremony in Silko'sCeremony.Rupkatha Journal on Interdisciplinary Studies in Humanities, 11.2 (July-Sept.):1-10.

EagleMan, Ed McGaa. 1990. Mother Earth Spirituality: Native American Paths to Healing Ourselves and Other World. New York: Harper Collins.

Eastman, Charles Alexander. 2003. The Soul of the Indian. New York: Dover Publications.

Erdrich, Louise. 1999. The Birchbark House. New York: Hyperion.

Garroutte, Eva Marie. 2003. Real Indians: Identity and the Survival of Native America. Berkeley. University of California Press.

Gilbert, Kevin. 1973. Because a White Man'll Never Do it. Sydney: Angus and Robertson.

Henderson, Dave. 2011. Leslie Marmon Silko and Simon J. Ortiz: Pathways to the tradition. Oral Tradition 26/2, 477-490.

Hogan, Linda. 1990. Mean Spirit. New York. Atheneum/MacMillan.

Horn, Gabriel. 2003. The Genocide of a Generations Identity. In Marijo Moore (Ed.) Genocide of the Mind. New York. Nation Books.

King, Thomas. 2012. The Inconvenient Indian. Canada. Anchor Canada.

Maddox, Lucy. 1991. Removals: Nineteenth-Century American Literature and the Politics of Indian Affairs. New York: Oxford University Press.

Mann, Barbara Alice. 2005. George Washington's War on Native America. Westport: Praeger.Page, Jake. 2003. In the Hands of the Great Spirit: The 20, ooo year History of American Indians. New York Free Press. 
Richter, Conrad. 1953. The Light in the Forest. New York: Everyman's Library.

Ross, Anne \& Kathleen Pickering. 2002. The politics of Reintegrating Australian Aboriginal

and American Indian Indigenous knowledge into Resource Management. The Dynamics of Resource

Appropriation and cultural Revival. Human Ecology 30.2 (Jun) 187-214.

Silko, Leslie Marmon. 1977. Ceremony. New York: Penguin Books.

Silko, Leslie Marmon.1991. Almanac of the Dead. New York: Penguin.

Smith, Sherry L. 2000. Reimaging Indians: Native Americans through Anglo Eyes, 1880-1940. New York: Oxford University Press.

Strong, Pauline Turner. 1986. Fathoming the Primitive: Australian Aborigines in Four Explorers" Journals, 1697-1845. Ethnohistory 33.2 (Spring): 175-194.

Strong, Paulina Turner, 1999. Captive Selves, Captivating others. The Politics and Poetics of Colonial American Captivity Narratives. Colorado: Westview Press.

Tinker, George E. 2003. Foreward. In VineDeloria Jr. God is Red. Colorado Fulcrum Publishing.

Trafzer, Clifford E. 1999. Exterminate Them: Written Accounts of the Murder, Rape and

Slavery of Native American During the California Gold Rush, 1848-1868. Michigan: Michigan State University Press.

Washburn, Wilcomb E. A Moral History of Indian-White Relations: Needs and Opportunities For Study.Ethnohistory 4.1 (Winter): 47-61.

Virender Pal Teaches English at Institute of Integrated \&Honors Studies, Kurukshetra University Kurukshetra. He has done his Ph.D. on Australian Aboriginal literature. He is the author of several academic papers and has completed a UGC sponsored minor project on "Debunking Dalit Stereotypes: A Study of U.R. Ananthamurthy's Novels." His interests include Native literature and Indian literature. His ORCID ID is oooo-0003-3569-1289. 